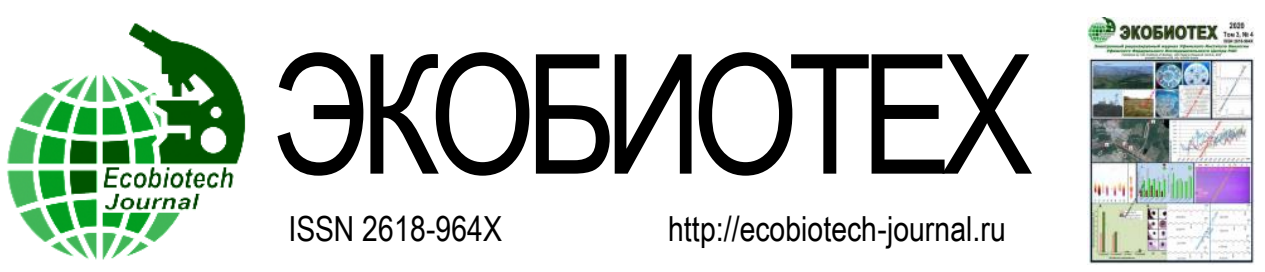

\section{PHOSPHATE SOLUBILIZING MICROORGANISM CONSORTIUM OF VIRGIN TIGER HILL FOREST SOIL SHOWS HIGH LEVEL TOLERANCE TO PESTICIDE, ANTIBIOTIC, ANTIFUNGAL AND HEAVY METALS}

\section{Saha S., Chakraborty S., Acharyya S., Sarkar S., Majumder S., Ghosh A., Bhattacharya M. ${ }^{*}$ \\ University Of North Bengal, Siliguri (India) "E-mail: malaytsnbu@gmail.com}

Tiger Hill, a notified reserve forest is the highest point around Darjeeling town in Eastern Himalayan Hotspot. Soil nutrition of this forest area depends on nutrient recycling where phosphate solubilising microorganisms (PSM) has crucial role to play as it solubilises insoluble phosphorus salt to soluble forms. But, with rise in use of toxic chemicals these microbes are at threat. This research initiative explores isolation of PSM from Tiger hill forest soil to detect pesticide, antibiotic, antifungal and heavy metal tolerance. Soil sample from tiger hill has moisture (18.55\%), pH (3.87), organic carbon (1.187\%), total Nitrogen (1.02\%) and Phosphorus in P2O5 form (10ppm). Isolation and screening of PSM were conducted on Pikovskaya's agar medium. In vitro tolerance assay was performed to detect degree of tolerance in isolated PSMconsortium (PSMC). Pesticides like Fipronil, Thiomethoxame, Emamectin benzoate, Deltamethrin, Flubendiamide, Spiromesifen, Fenazaquin and Phorate exhibited complete to high degree of tolerance. PSMC was fully tolerant to antibiotic like Augmentin, Erythromycin, Chloramphenicol, Ofloxacin, CoTrimoxazole, Cefotaxime; antifungal Itraconazole and Fluconazole. Mild tolerance towards heavy metal salts like As2O3, $\mathrm{SnCl} 2, \mathrm{CdCl} 2, \mathrm{CuCl} 2, \mathrm{CdSO} 4$ and $\mathrm{CuSO} 4$ were detected. Synergestic effect of cells present in the isolated PSMC may also be an added advantageous property to tolerate pesticides, antibiotic, antifungal and heavy metal salts.

Keywords: antibiotic, antifungal, heavy metal, pesticide, soil, Tiger Hill, tolerance

Поступила в редакичию: 22.06.2020

\section{КОНСОРЦИУМ ФОСФАТСОЛЮБИЛИЗИРУЮЩИХ МИКРООРГАНИЗМОВ ДЕВСТВЕННОЙ ЛЕСНОЙ ПОЧВЫ ТАЙГЕР-ХИЛЛ ДЕМОНСТРИРУЕТ ВЫСОКУЮ ТОЛЕРАНТНОСТЬ К ПЕСТИЦИДАМ, АНТИБИОТИКАМ, ПРОТИВОГРИБКОВЫМ ПРЕПАРАТАМ И ТЯЖЕЛЫМ МЕТАЛЛАМ \\ Саха С., Чакраборти С., Ачарья С., Саркар С., Маджумдар С., Гхош А., Бхаттачарья М. \\ Университет Северной Бенгалии, Силигури (Индия) "E-mail: malaytsnbu@gmail.com}

Тайгер Хилл, лесной заповедник, является самой высокой точкой в окрестностях города Дарджилинг в Восточных Гималаях. Питание почвы этой лесной зоны зависит от рециркуляции питательных веществ, где фосфатсолюбилизирующие микроорганизмы (PSM) играют решающую роль, так как превращают нерастворимые соли фосфора в растворимые. Но с ростом использования токсичных химических веществ эти микробы находятся под угрозой. В работе выделены PSM из лесной почвы Тайгер-Хилл для определения толерантности к пестицидам, антибиотикам, противогрибковым препаратам и тяжелым металлам. Образец почвы с тигрового холма содержит влагу $(18,55 \%), \mathrm{pH}(3,87)$, органический углерод $(1,187 \%)$, общий азот $(1,02 \%)$ и фосфор в форме $\mathrm{P}_{2} \mathrm{O}_{5}$ $(10 \mathrm{ppm})$. Выделение и скрининг PSM проводили на агаровой среде Пиковской. Для определения степени толерантности в изолированном PSM-консорциуме (PSMC) был проведен анализ толерантности in vitro. Пестициды (фипронил, тиометоксан, эмамектин бензоат, дельтаметрин, флубендиамид, спиромезифен, феназахин и форат) проявляли полную и высокую степень переносимости. PSMC была полностью толерантна к таким антибиотикам (аугментин, эритромицин, хлорамфеникол, офлоксацин, ко-тримоксазол, цефотаксим), противогрибковым итраконазолу и флуконазолу. Обнаружена умеренная толерантность к солям тяжелых металлов $\left(\mathrm{As}_{2} \mathrm{O} 3, \mathrm{SnCl}_{2}, \mathrm{CdCl}_{2}\right.$, $\mathrm{CuCl}_{2}, \mathrm{CdSO}_{4}$ и $\left.\mathrm{CuSO}_{4}\right)$. Синергетический эффект присутствующих в изолированном PSMC клеток может быть дополнительно выгодным свойством невосприимчивости к пестицидам, антибиотикам, противогрибковым препаратам и солям тяжелых металлов.

Ключевые слова: антибиотик, противогрибковый, тяжелый металл, пестицид, почва, Tiger Hill, толерантность 


\section{INTRODUCTION}

The Darjeeling Hills form a major hill terrain in the north of the Indian state of West Bengal. They comprise largely of the outer and lower Himalayan Ranges. The southernmost tract comprises of the Siliguri area which is a transition zone between the outer Himalaya and the plains of North Bengal while the Darjeeling hills mainly lie to the south of the Rangit river gorge.

Tiger hill is the highest point around Darjeeling town. Traditionally it is known as Gangz La (also called Point 5062). It lies in the centre of the hill tract. Situated at a height of 2,590 m at a distance of $13 \mathrm{~km}$ from the Darjeeling town and above Ghum, Tiger Hill is internationally acclaimed for providing an enthralling view of a stunning sunrise over Mt. Kanchenjunga and other important peaks of the Himalayas. The world's highest peak, Mount Everest can be glimpsed from here. The Tiger Hill area was notified as a reserved forest in 1998 according to an article in the Telegraph India published on $2^{\text {nd }}$ September 2015 [https://www.telegraphindia.com/states/west-bengal/cmboost-to-tiger-hill/cid/1523530]. It is a 21 hectare Local Nature Reserve between Bures St Mary and Leavenhealth in Suffolk. It is owned by Suffolk County Council and managed by the Tiger Hill LNR Management Committee. The site is in the Dedham Vale Area of Outstanding Natural beauty, and most of it (excluding a narrow strip of land in the north) is part of the Arger Fen Site of Special Scientific Interest. This site has woodland, heath and fenland, and fauna include badgers, bats and rare and endangered dormice.

Tiger hill forest, though close to human habitat is an unmanaged ecosystem. Nutrient recycling from green litter replenishes the soil by the aid of soil microflora. In this group of helpful soil microbes, phosphate solubilising microorganisms have some crucial role to play. Phosphorus is one of the major macronutrient required for plant growth and metabolism. But, this element remains unavailable to plants due to its fixation with other metallic elements to form their respective salts in soil. Plant cell might take up several forms of Phosphorus, but the greatest part of it is absorbed in the forms of phosphate anions mainly [Rodríguez et al., 1999; Mahidi et al., 2011; Walpola et al., 2012; Satyaprakash et al., 2017; Kumar et al., 2018].The main input of inorganic Phosphorus in agricultural soil is by applying phosphorus fertilizers. In case of natural forests phosphorus is obtained by plants from organic source or from rocks by action of phosphate solubilising microorganisms (PSMC). But, with rise in anthropogenic activities and paramount abuse of chemicals in agricultural fields, soil microbes are at threat. Thus there is a need to explore microbial diversity which can either transform toxic chemicals pesticides to non-toxic forms or could survive in presence of their high concentrations as a part of natural bioremediation. So, the consortium of phosphate solubilising microorganisms (PSM), having resistance to high concentrations of toxic pesticides is an attractive option for enriching soil with soluble phosphates.

Except studies on flora and fauna, Tiger hills remain unexplored by scientific community. There is neither any report on isolation of phosphate solubilising microbes in this region or on its tolerance amplitude. So, this research initiative was undertaken to isolate PSM from soil of Tiger hill forests and workout their tolerance against pesticide, antibiotic, antifungal agents and heavy metal salts.

\section{MATERIALS AND METHODS}

\section{Collection of soil samples}

Topsoil was collected from the edge of the woods that shelve steeply down the cliff in the Tiger Hill after the first shower in the month of April, 2019. Twenty pre-samples were collected 
randomly from sites fifty metre apart. The samples were placed in sterile zipper bags, sealed properly, labelled and stored temporarily in ice pack filled Styrofoam box. Other information like latitude, longitude, elevation, soil temperature, etc. of the collection site was recorded. The samples were brought back to laboratory and were mixed thoroughly to make the working sample for further downstream experiments.

\section{Soil analysis}

$\mathrm{pH}$, moisture, organic carbon (OC), organic matter $(\mathrm{OM})$ content, total nitrogen and available phosphorus content of the collected soil sample was analysed. The collected soil sample was completely air dried. Debris from the sample like plant root, pebbles etc. were hand-picked. The clean air dried sample was passed through $2 \mathrm{~mm}$ sieve and crushed with mortar and pestle. For organic carbon determination, the sample was further passed through a finer mesh sieve $(0.5 \mathrm{~mm})$.

Estimation of soil $\mathrm{pH}$ was conducted by adding $20 \mathrm{~g}$ of air dried soil sample to $50 \mathrm{ml}$ of neutral water and mixed thoroughly over a mechanical shaker for 30 minutes. The contents of the conical flask were transferred to a beaker. Finally, previously calibrated electrode of a soil $\mathrm{pH}$ meter was dipped into the beaker to measure the soil $\mathrm{pH}$. Three replicates were tested for each sample and their $\mathrm{pH}$ was calculated [Barua and Barthakur, 1997].

Quantification of soil organic carbon was conducted by Chromic acid method proposed by Walkley and Black, [Walkley, 1947] with minor modification. 0.5g of air dried and sieved soil was taken in a conical flask. $10 \mathrm{ml}$ of $1 \mathrm{~N}$ Potassium dichromate $\left(\mathrm{K}_{2} \mathrm{Cr}_{2} \mathrm{O}_{7}\right)$ solution and $20 \mathrm{ml}$ of conc. $\mathrm{H}_{2} \mathrm{SO}_{4}$ was added to it. The flask was allowed to stand for 30 minutes for completing the reaction. $170 \mathrm{ml}$ of water was poured to the flask to dilute the suspension. After adding $0.2 \mathrm{~g}$ of Sodium fluoride $(\mathrm{NaF})$ and $1 \mathrm{ml}$ of diphenylamine indicator, back titration was conducted with $0.5 \mathrm{~N}$ ferrous ammonium sulphate, till the colour changed from violet through blue to bright green. The volume of the ferrous ammonium sulphate was noted. One blank (without soil) titration was done in a similar manner. Percentage of organic Carbon in the soil was calculated by:

$\%$ of organic Carbon in the soil $=\{0.5 \times(\mathrm{B}-\mathrm{S}) \times \mathrm{N} \times 0.003 \times(100 / \mathrm{W})\} \times \mathrm{C}$

Where; $\mathrm{B}=$ blank reading, $\mathrm{S}=$ sample reading, $\mathrm{N}=$ represents the normality of $\mathrm{K}_{2} \mathrm{Cr}_{2} \mathrm{O}_{7} \mathrm{Sol}^{\mathrm{n}}$, $\mathrm{W}=$ weight of soil taken and $\mathrm{C}=$ correction factor.

Total soil Nitrogen was determined by Kjeldhal method [Jackson, 1973] with minor modifications. One gram of air dried sample was added to $5 \mathrm{~g}$ of digestion mixture (5:1:: $\mathrm{K}_{2} \mathrm{SO}_{4}: \mathrm{CuSO}_{4}$ ) followed by $20 \mathrm{ml}$ of concentrated $\mathrm{H}_{2} \mathrm{SO}_{4}$. The mixture was heated at $420^{\circ} \mathrm{C}$ in an automated Kjeldhal digestion tube until the solution turns to blue colour. The digested solution after cooling was transferred to $100 \mathrm{ml}$ volumetric flask. $20 \mathrm{ml}$ of digested sample was taken in automated Kjeldhal distillation tube, $20 \mathrm{ml} 40 \% \mathrm{NaOH}$ and $10 \mathrm{ml}$ distilled water was added to it. The reaction mixture was distilled and the ammonia released was absorbed in $10 \mathrm{ml}, 2 \%$ boric acid solution (containing mixed indicator of Bromocresol Green and Methyl Red) in a 100ml conical flask. Distillation was conducted until the colour change of boric acid from purple to green was prominent. The trapped ammonia in boric acid was titrated against $0.05 \mathrm{~N} \mathrm{H}_{2} \mathrm{SO}_{4}$. One blank sample was run in a similar manner.

Calculation was conducted as\% total Nitrogen in soil $=0.014 \times \mathrm{S} \times \mathrm{V} \times \mathrm{df} \times 100$

Where, $\mathrm{S}=$ Strength of $\mathrm{H}_{2} \mathrm{SO}_{4}, \mathrm{~V}=$ Volume required and $\mathrm{df}=$ Dilution factor

One gram sample was subjected to diacid digestion for available phosphate and final volume was adjusted to $100 \mathrm{ml}$ [Barua and Barthakur, 1997]. Available phosphorus in the digested sample solution in form of phosphate was conducted by the protocol developed by Bray and Kurtz, 1945. 
$10 \mathrm{ml}$ of digested sample was taken in volumetric flask. The phosphate content in the solution was measured in precalibrated spectrophotometer $(660 \mathrm{~nm})$ by adding ammonium molybdate and thereafter reducing the molybdenum-phosphate complex with stannous chloride $(2 \mathrm{ml})$ to make it 50ml [Jackson, 1973]. Quantification of phosphate (ppm) was calculated by the following equationQuantification=Concentration (ppm) X dilution factor.

\section{Isolation and authentication of PSM}

Phosphate solubilising microorganisms was isolated using a selective media (Pikovskaya's agar). 500mg of collected soil sample was weighed being careful to exclude any stone chips, and was mixed with $1 \mathrm{ml}$ of sterile distilled water in an autoclaved eppendorf. The solution was then vortexed for a minute ensuring proper mixing of the soil. From this sample solution $500 \mu 1$ was pipetted into one-fourth strength of autoclaved Pikovskaya's agar media. The culture was then incubated at $30^{\circ} \mathrm{C}$ for 48 hours.

The isolated culture was then placed on Pikovskaya's agar plates for further screening and authentication of phosphate solubilising activity by appearance of halo around the colonies [Cao, et al., 2018]. The colonies showing prominent halo were picked by sterile loops and mixed to make the phosphate solubilising microorganism consortium. The isolate was further cultured in Pikovskaya's media to preserve at $4^{\circ} \mathrm{C}$ for further downstream experiments.

\section{Pesticide tolerance assay}

Nine common pesticides that are normally used were chosen to test the tolerance level (if any) and pattern of the isolated phosphate solubilising microorganisms. $100 \mu 1$ of the isolated culture was pour plated in a petri dish with Pikovskaya's media. $100 \mu 1$ of four different concentrations $-2.5,5,10$ and $20 \mathrm{mg} / 1 \mathrm{ml}$ of the nine pesticides were added in the bored wells of the petri plates and incubated at $30^{\circ} \mathrm{C}$ for 48 hours. The concentrations were chosen keeping in mind the actual dosage that is usually recommended, followed by gradual increase upto 8 times the prescribed value.

\section{Antibiotic tolerance assay}

In vitro antibiotic tolerance assay was conducted for the isolated culture using antibiotic discs. Common antibiotics - Bacitracin (B10), Chloramphenicol (C30), Penicillin-G (P10), Polymyxin B (PB300), Gentamicin (GEN10), Neomycin (N30), Cefotaxime (CTX30), Augmentin (AMC30), Erythromycin (E10), Ofloxacin (OF5) and Co-Trimoxazole (COT25) were used in 100 $\mu 1$ of isolated culture that was pour plated in Pikovskaya's media.

\section{Antifungal tolerance assay}

In vitro antifungal tolerance was tested for the isolated culture using antifungal discs. Six common antifungals - Amphotericin-B (AP100), Clotrimazole (CC10), Fluconazole (FLC25), Itraconazole (IT10), Ketoconazole (KT10) and Nystatin (NS100) were used in $100 \mu$ l of isolated culture that was pour plated in Pikovskaya's media.

\section{Heavy metal tolerance assay}

Heavy metal tolerance test was conducted since Tiger hills is a part of the Sub-Himalayan range which is a young fold mountain formed by the continental collision between the IndoAustralian plate and the Eurasian plate, completely closing the Tethys Ocean and thus consisting 
mainly of sedimentary and metamorphic rock [Bhattacharya, 2014]. Salts of $\mathrm{As}_{2} \mathrm{O}_{3}$ [Arsenite oxide], $\mathrm{SnCl}_{2}$ [Stannous chloride], $\mathrm{CdCl}_{2}$ [Cadmium chloride], $\mathrm{CuCl}_{2}$ [Copper (II) chloride], $\mathrm{CdSO}_{4}$ [Cadmium sulphate], $\mathrm{CuSO}_{4}$ [Copper(II) sulphate] and $\mathrm{HgCl}_{2}$ [Mercuric chloride] were tested at two different concentrations of $2.5 \mathrm{mg} / \mathrm{ml}$ and $5 \mathrm{mg} / \mathrm{ml} .1 \mathrm{ml}$ of isolated culture was pour plated in petri plates using Pikovskaya's media and sterile discs dipped in heavy metal solution was placed on the solid media and inhibition was studied using radial diffusion method. The plates were incubated at $30^{\circ} \mathrm{C}$ for 48 hours.

\section{RESULTS AND DISCUSSION}

\section{Collection of soil samples}

Tiger hill forest Darjeeling was considered for the present study (fig. 1). Showers prior to pre-monsoon triggers soil microbial activities, so this particular season was chosen for soil collection. Pre-sample collection sites were randomly chosen to minimise error. The centrally located pre-sample collection site $\left(26.5429^{\circ} \mathrm{N}\right.$ and $\left.88.1709^{\circ} \mathrm{E}\right)$ had elevation of 8484 feet $(2585.923$ m) with a soil temperature of $8^{\circ} \mathrm{C}$. Pre-sample mixing, sterile zipper bags and ice-packing were undertaken to avoid error during sampling, contamination and degradation respectively.
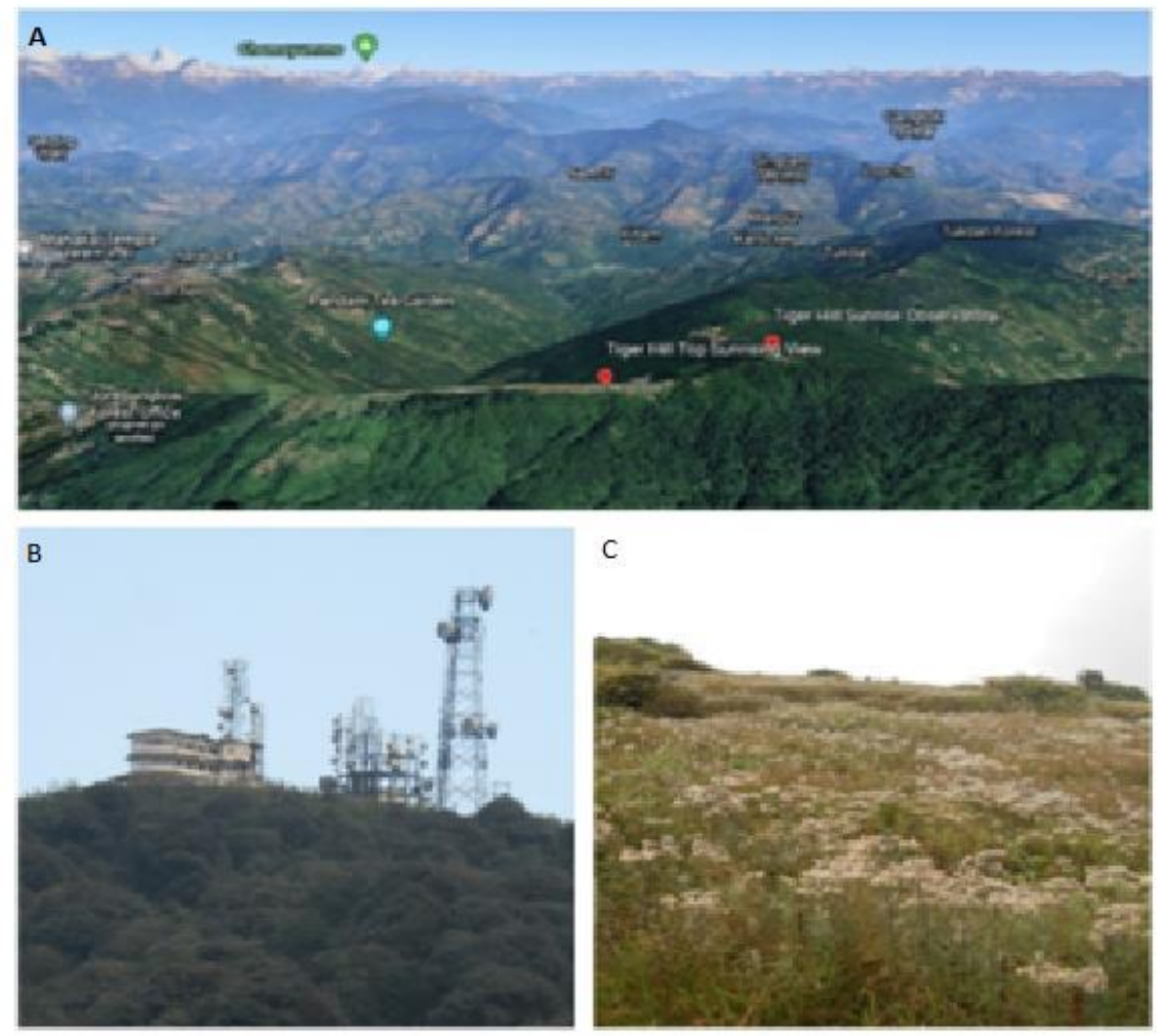

$\mathrm{C}$

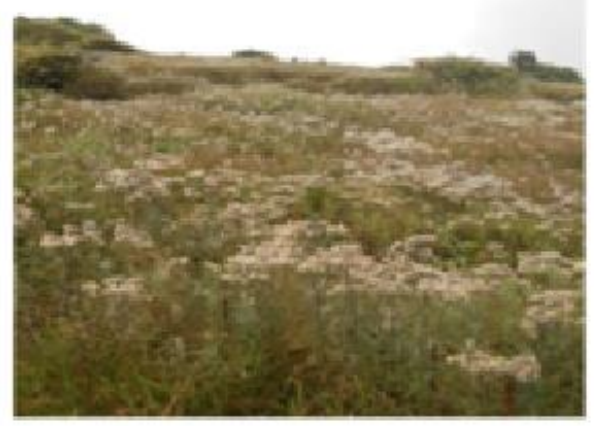

Fig. 1. A - Google photograph of Tiger hills, B - Tiger hill sunrise observatory and C - a part of soil collection site

\section{Soil analysis}

Soil analysis is a prerequisite to detect the nutritional status of collected soil samples, as autotrophs and soil microorganisms depend on soil nutrients for their growth. Moisture in soil is very important for survival of plants and microbes. Moisture percentage of collected soil sample was $18.55 \%$. $\mathrm{pH}$ of the soil sample was found to be 3.87. Organic carbon and organic matter are considered as indicator of organic richness of soil. Percentages of organic carbon and organic 
matter were 1.187 and $2.042 \%$ respectively. Percentage of total Nitrogen in the collected soil sample was $1.02 \%$. Phosphorus as $\mathrm{P}_{2} \mathrm{O}_{5}$ was recorded to be $10 \mathrm{ppm}$.In a previous report Bhattacharya, 2014 described Darjeeling soil as brown, loamy in nature, acidic in reaction and rich in organic matter and nutrients.

\section{Isolation and authentication of PSMC}

Pikovskaya's agar media selective for phosphate solubilising microorganisms were used to isolate the microbes. Phosphate solubilising microorganisms produce halo on Pikovskaya's agar media [Cao, et al., 2018]. So, further screening and authentication of phosphate solubilising microorganisms were judged by the magnitude of halo produced by the colonies. Mixing of colonies showing halo to make the working phosphate solubilising microorganism consortium (PSMC) was done to involve all possible phosphate solubilising microorganisms of the study area.

\section{Pesticide tolerance assay}

In vitro tolerance assay was performed to detect degree of tolerance in isolated PSMC. Pesticides are not only toxic to the spraying personals but are even harmful to the ecosystem as they accumulate in soil. Based on survey of nearby markets nine most abundantly used pesticides were selected for our present study. Over passage of time pesticides degrade or accumulate in soil to modify microbes inhabiting in it. They induce modification of soil micro-flora by death and decline or may incite tolerance for resisting pesticides.

The isolated PSMC exhibited variable degree of tolerance against pesticides (fig. 2).Four different concentrations $(2.5,5,10$ and $20 \mathrm{mg} / \mathrm{ml})$ of pesticides were studied to assess their effect of concentration on growth of PSMC. Two pesticides, Fipronil and Thiomethoxame showed no inhibition zone at all in the studied concentrations. So, PSMC is tolerant to all concentrations of pesticides. Emamectin benzoate showed inhibition only at highest concentration $(20 \mathrm{mg} / \mathrm{ml})$ as PSMC have tolerance to lower concentrations. Deltamethrin showed density gradient increase in inhibition zones in all the higher concentrations $(5,10$ and $20 \mathrm{mg} / \mathrm{ml})$ but there was no inhibition in its lowest concentration $(2.5 \mathrm{mg} / \mathrm{ml})$. Pesticides like Flubendiamide, Spiromesifen, Fenanzaquin and Phorate showed a gradual increase in inhibition zone with increase in concentration. Quinalphos showed same magnitude of inhibition zone in all the tested concentrations for inability of PSMC withstand Quinalphos even at its lowest concentrations.

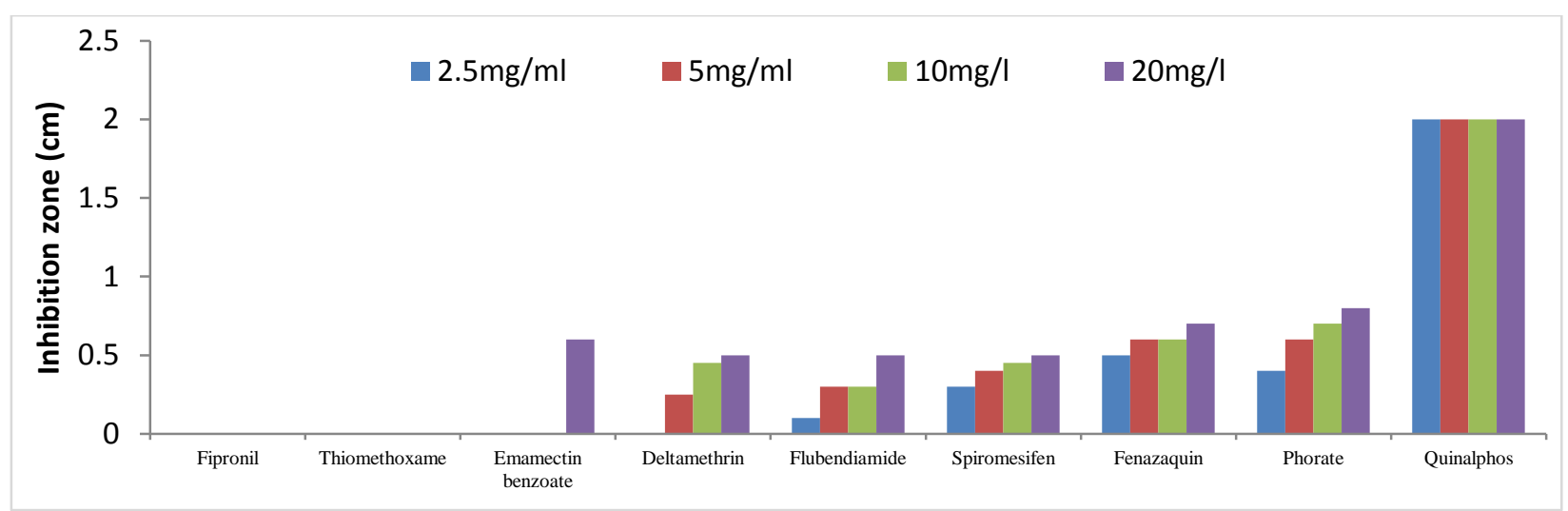

Fig. 2. Inhibition zones exhibited by concentrations of pesticide on PSMC

Summative representation of overall data depicting the variable tolerance level of the PSMC is shown in fig. 3. Out of the nine pesticides tested Fipronil and Thiomethoxame showed no inhibition zones. So, the isolated PSMC was completely tolerant to these two pesticides. Emamectin 
benzoate showed least while Quinalphos showed maximum inhibition zone. Pesticides like Fipronil, Thiomethoxame, Emamectin benzoate, Deltamethrin, Flubendiamide, Spiromesifen, Fenazaquin and Phorate showed complete to high degree of tolerance. Based on the results Quinalphos can be considered as least tolerant pesticide for the isolated PSMC.

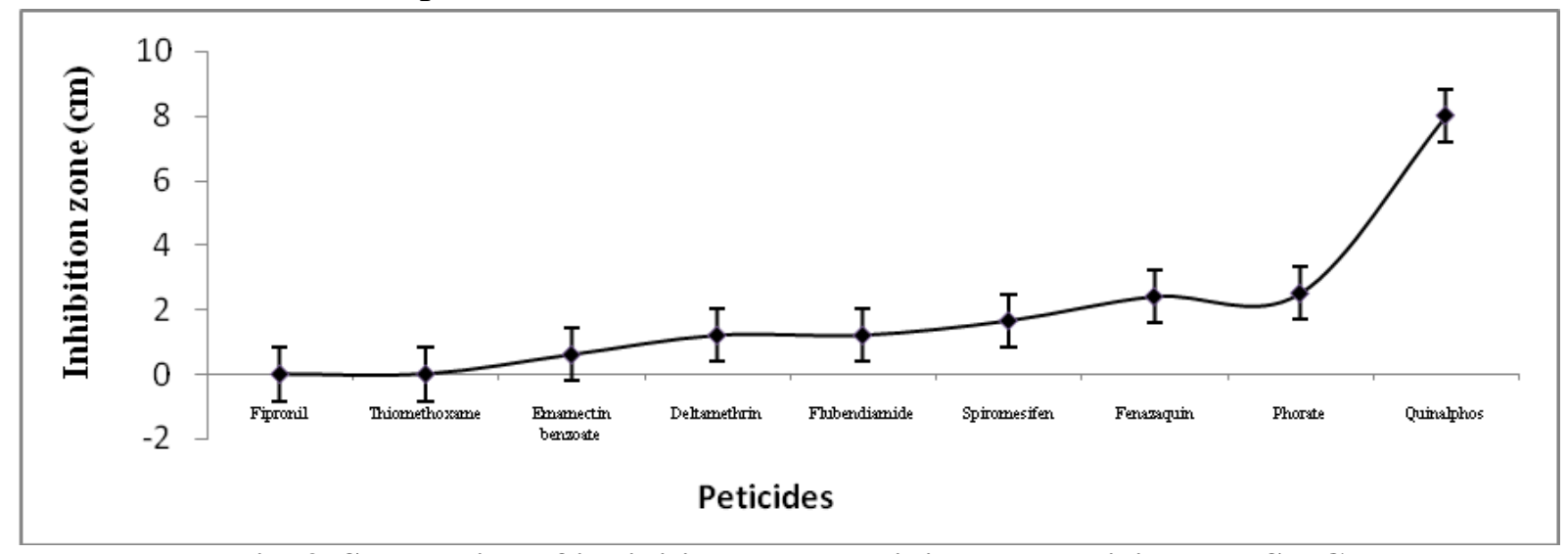

Fig. 3. Summation of inhibition zones exhibited by pesticide on PSMC

\section{Antibiotic tolerance assay}

Antibiotics after its discovery had widespread use all over the world not only as an antibacterial agent in medicines, but also in animal husbandry and agricultural fields. These antibiotics accumulate in soil and water declining useful microbes that in turn helps in increasing the fertility of the soil [Cycon, et al., 2019]. This also helps in developing antibiotic resistant microbes. Taking this assumption into consideration, we studied the antibiotic resistance ability gained by our isolates. Figure 4 is a total representation of the summative data for antibiotic tolerance assay in a nutshell. Out of the twelve antibiotics tested AMC30, E10, C30, OF5, COT25 and CTX30 showed no inhibition zones. Mild inhibition zones were produced by PB300, N30, GEN 10 and B10 while high inhibition zone was produced by P10. So it can be assumed that antibiotics like AMC30, E10, C30, OF5, COT25 and CTX30 are fully tolerant to our isolated PSMC. Other antibiotics like PB300, N30, GEN10 and B10 are high while P10 is mild tolerant.

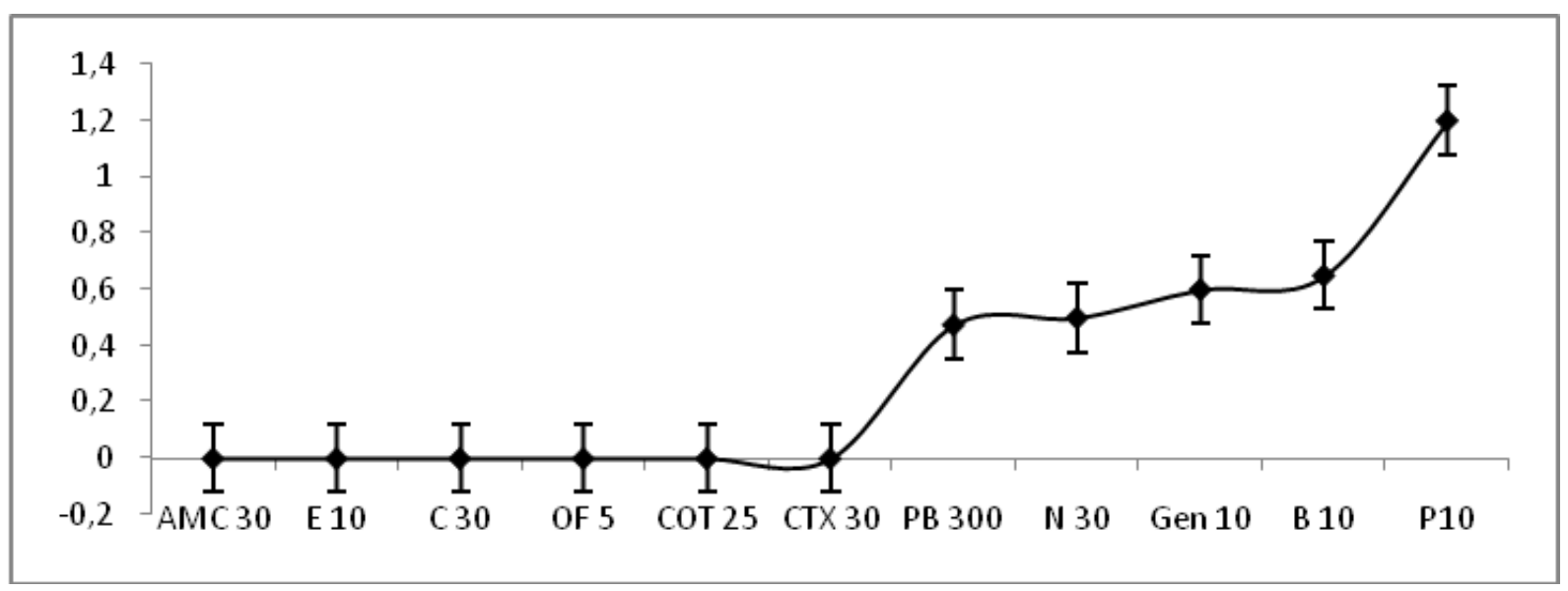

Fig. 4. Summation of inhibition zones exhibited by antibiotic on PSMC

\section{Antifungal tolerance assay}

Antifungal resistance has emerged just like antibiotic resistance due to improper usage of antifungal agents. So, antifungal tolerance assay was conducted to examine if the isolate PSMC had any tolerance against antifungal as well. The summative data for antifungal tolerance assay in a nutshell is depicted in Figure 5. Out of the six antifungal agents tested IT10 and FLC 25 showed 
minimum inhibition zones. KT10, AP100 and CC10 showed mild but NS100 showed highest inhibition zone. So, it can be considered that IT10 and FLC25 are completely tolerant. KT10, AP100 and CC10 are high while NS100 is mild tolerant.

According to a study, azole fungicides constitute the most widely used class of antifungal agents for control of fungal plant pathogens [Jensen and Jorsen, 2013]. Out of the six commonly used antifungals that were screened for this assay, four of them (IT10, FLC25, KT10 and CC10) were of azole group. Two of them (IT10 and FLC25) are completely tolerant while the other two (KT10 and CC10) are highly tolerant.

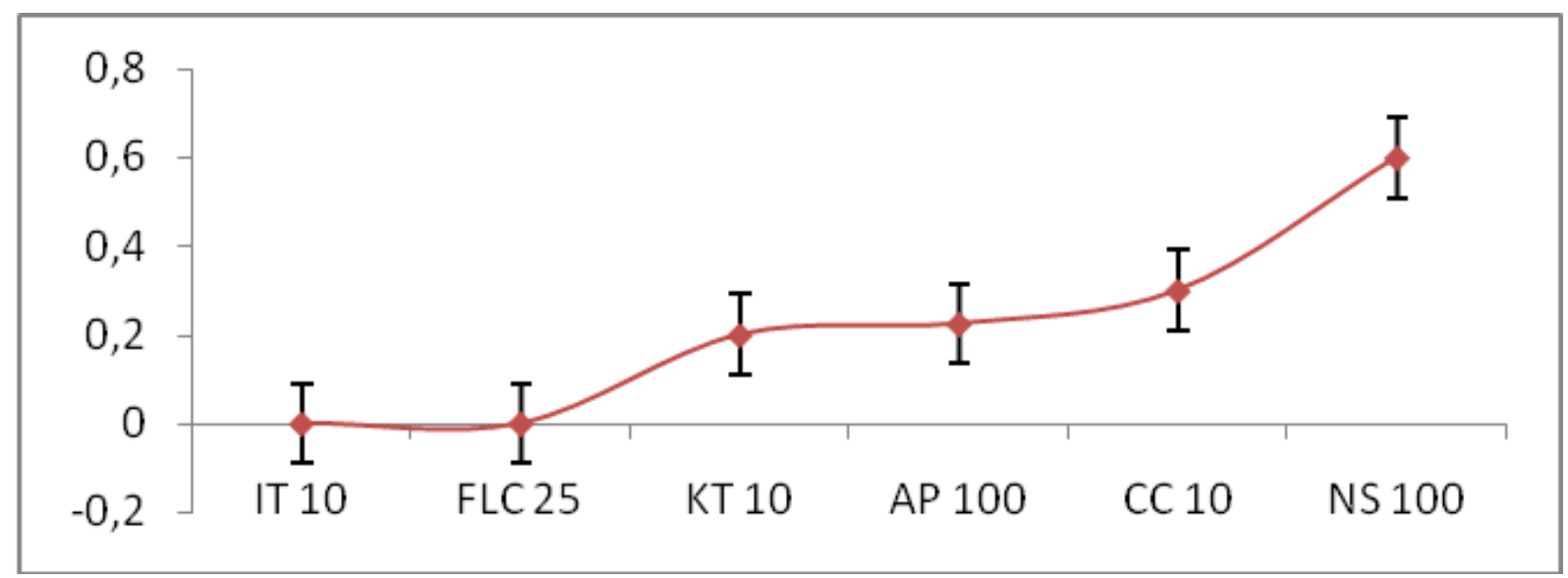

Fig. 5. Summation of inhibition zones exhibited by antifungal on PSMC

\section{Heavy Metal tolerance}

Heavy metals in soil can be introduced by two major ways- natural and by anthropogenic activities. Natural ways of introduction includes geology of the region and weathering of rocks whereas anthropogenic sources may include industrialism, agricultural activities and/or tourism. Metal contamination poses serious cytotoxic threats to living cells even in minute quantities. The stressful conditions often induce tolerance ability in the microbes. Therefore we considered to test for heavy metal tolerance among the PSM isolates.

The inhibition zone produced by some heavy metals on isolated PSMC from Tiger hill soil is depicted in figure 6. Inhibition zone produced by $\mathrm{As}_{2} \mathrm{O}_{3}, \mathrm{SnCl}_{2}, \mathrm{CdCl}_{2}, \mathrm{CuCl}_{2}, \mathrm{CdSO}_{4}$ and $\mathrm{CuSO}_{4}$ was less but in case of $\mathrm{HgCl}_{2}$ the inhibition zone was much higher compared to other heavy metal salts. $\mathrm{CuSO}_{4}$ in concentration of $5 \mathrm{mg} / \mathrm{ml}$ showed a high rise in the inhibition zone against $2.5 \mathrm{mg} / \mathrm{ml}$. So, it can be assumed that the isolated PSMC is mild tolerant towards $\mathrm{As}_{2} \mathrm{O}_{3}, \mathrm{SnCl}_{2}$, $\mathrm{CdCl}_{2}, \mathrm{CuCl}_{2}, \mathrm{CdSO}_{4}$ and $\mathrm{CuSO}_{4}$ but less tolerant towards $\mathrm{HgCl}_{2}$.

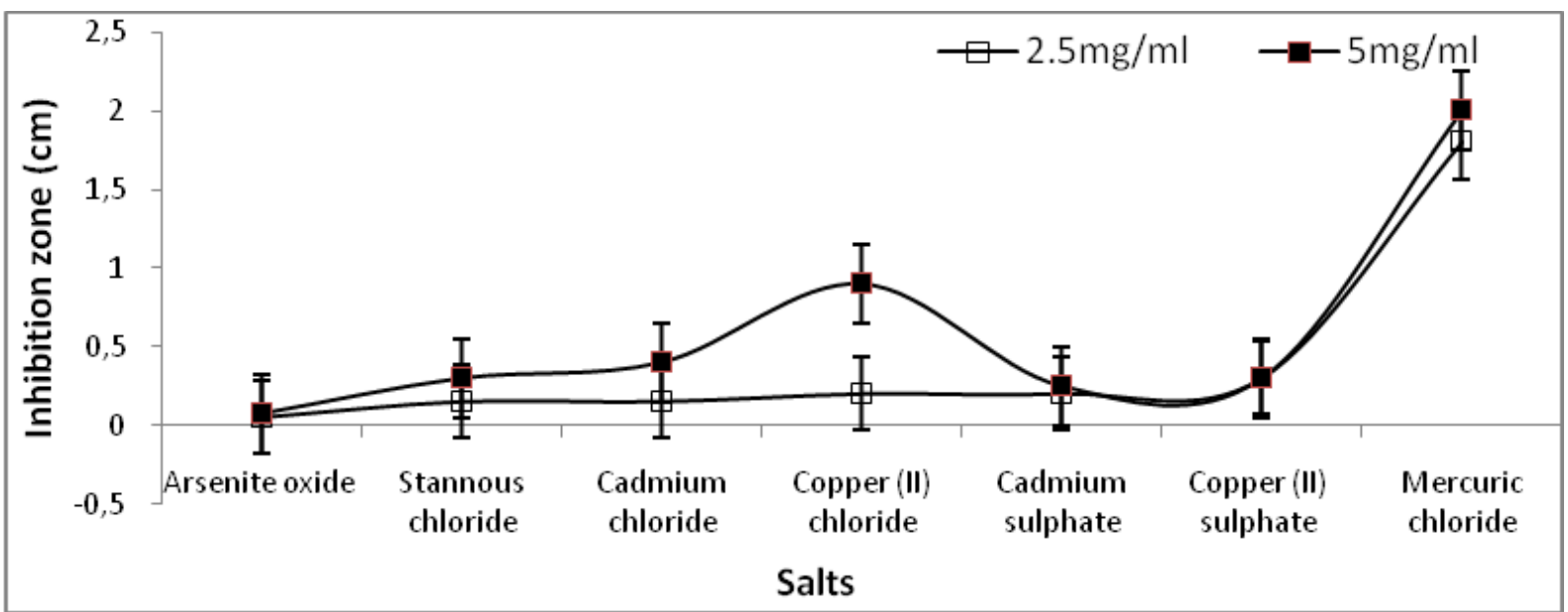

Fig. 6. Summation of inhibition zones exhibited by heavy metals on PSMC 


\section{Tolerance of isolated PSMC}

In vitro assay of isolated PSMC showed variable degree of tolerance (Fig 7). During our experiment we have noted that there was no inhibition of isolated PSMC growth by some pesticide, antibiotic and antifungal. In our plates $22.2 \%$ of the pesticides, $54.54 \%$ of antibiotic and $33.33 \%$ of antifungal tests showed no inhibition zones. So, it may be logical to say that the isolated PSMC is fully tolerant to these pesticide (Fipronil and Thiomethoxame), antibiotic (AMC30, E10, C30, OF5, COT25 and CTX30) and antifungal (IT10 and FLC25) agents. Similarly, high tolerance was recorded for $66.66 \%$ of the pesticides (Emamectin benzoate, Deltamethrin, Flubendiamide, Spiromesifen, Fenanzaquine and Phorate), 36.66\% of antibiotic (PB300, N30, GEN10 and B10) and $50 \%$ of antifungal (KT10, AP100 and $\mathrm{CC} 10$ ) agents. Except $\mathrm{HgCl}_{2}$ our isolated PSMC showed high tolerance against all other tested heavy metal salts.

Exhibition of such high level pesticide tolerance our isolated PSMC is a matter of surprise for us. Tiger hill forest being situated at an elevation of $2,590 \mathrm{~m}$ is the highest point in close vicinity of Darjeeling town, so the question of pesticide accumulation from nearby agricultural fields along flow of rain water does not arise. Moreover, the area remains undisturbed except tourist movement to the sunrise observatory. We have tried our best to avoid places with human activities to collect soil samples. Thus, it may not be ideal to put a conclusive statement regarding the origin of pesticide tolerant property in the isolated PSMC. Pesticides like Fipronil \& Imidacloprid (act and disrupts central nervous system), Phorate and Quinalphos (acetylcholinesterase inhibotor), Emamectin benzoate (inhibits muscle contraction), Thiomethoxame (interferes with nicotinic acetylcholine receptors in central nervous system), Fenazaquin (mitochondrial NADH:ubiquinone reductase inhibitor), Spiromesifen (inhibitor of lipid synthesis), Deltamethrin (neurotoxin) and Flubendiamide (ryanodine receptor modulator) are notable pollutants so gaining tolerance against PSMC requires special attention.

Microorganisms express tolerance to antibiotic and/or antifungal molecules by undergoing mutations, acquiring plasmids and by adapting to the environment having concentrations below minimum inhibitory concentration [Davies and Davies, 2010; Blair, et al., 2015; Alekshun and Levy, 2007; Wright and Poinar, 2012]. Some microbes also evolve various mechanisms like presence of a permeability barrier that prevents diffusion, activating efflux pumps which expels specific molecules reducing its availability at target sites, alterations in molecular targets, presence of metabolic bypass that renders the cell insensitive, presence of antibiotic-altering and antibioticdegrading enzymes to endure antibiotic and antifungal agents [Blair, et al., 2015; Lubelski, et al., 2007; Wright, 2011; Wright, 2012]. Moreover as we worked on phosphate solubilizing consortium of microorganism, so presence of cells producing antibiotic or antifungal molecules under natural conditions could have induced the antibiotic or antifungal susceptible soil microbes to gain mechanisms to resist antibiotics and antifungal agents. Synergestic effect of cells present in the isolated PSMC may also be an added advantageous property of the consortium to tolerate antibiotics and antifungals.

Heavy metals such as mercury $(\mathrm{Hg})$, chromium $\left(\mathrm{Cr}^{6+}\right)$, arsenic $(\mathrm{As})$, cadmium $(\mathrm{Cd})$, etc cause toxic effects on plants, soil and living organisms even in minute concentration and they do not have any biological role [Gupta, et al., 2016; Igiri, et al., 2018]. Moreover, heavy metals even at lower concentrations have been reported as cytotoxic and developed cancer in humans [Dixit, et al., 2015]. Tolerance property of PSMC against heavy metal salts like $\mathrm{As}_{2} \mathrm{O}_{3}, \mathrm{SnCl}_{2}, \mathrm{CdCl}_{2}, \mathrm{CuCl}_{2}$, $\mathrm{CdSO}_{4}, \mathrm{CuSO}_{4}$ and $\mathrm{HgCl}_{2}$ is a matter of concern as tolerance might have been induced by presence of these salts in soil. 

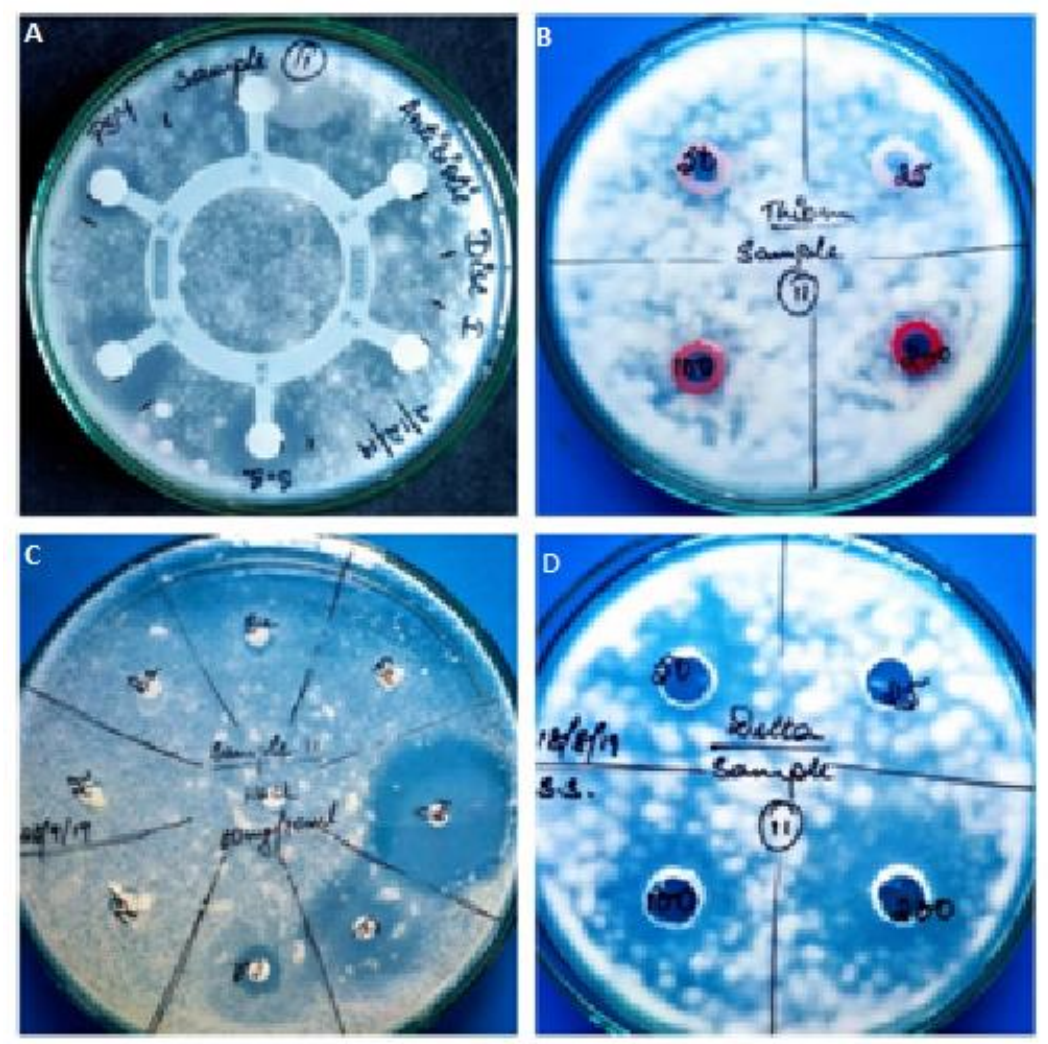

Fig. 7. Plates showing tolerance and/or susceptibility A-antibiotic, B-pesticide tolerance, C-heavy metal and D-pesticide susceptible

\section{CONCLUSION}

Soil nutrient cycle of virgin forests depend on microflora. Phosphate solubilising microorganism consortium takes charge of converting insoluble phosphorus to soluble forms. But, it is a matter of great concern that soil microfloral diversity and its tolerance pattern is changing very fast. But, why and how the microbes of virgin soil gain tolerance require to be investigated. However, exploiting tolerant consortium of microbes in degraded forest soil can open up a new dimension for restoring soil nutrient status.

\section{ACKNOWLEDGEMENT}

The authors would like to acknowledge Mr. Shantoshubhro Bhattacharya for clicking and arranging the photographs of Tiger hill.

\section{REFERENCES}

1. Alekshun M.N., Levy S.B. Molecular mechanisms of antibacterial multidrug resistance // Cell. 2007. V. 128 (6). P. 1037-1050.

2. Baruah T.C., Barthakur H.P. A Text Book of Soil Chemical Analysis. Vikash, New Delhi. 1997.

3. Bhattacharya M. Floral components of Darjeeling with special reference to its forest areas. A Comprehensive District Profile of Darjeeling. N.L. Publishers, West Bengal. 2014.

4. Blair J.M.A., Webber M.A., Baylay A.J., Ogbolu D.O., Piddock L.J.V. Molecular mechanisms of antibiotic resistance//Nature reviews microbiology. 2015 . V. 13 (1). P. 42-51.

5. Bray R.H., Kurtz L.T. Determination of total, organic, and available forms of phosphorus in soils // Soil science. 1945. V. 59 (1). P. 39-46. 
6. Cao Y., Fu D., Liu T., Guo G., Hu Z. Phosphorous solubilizing and releasing bacteria screening from the rhizosphere in a natural wetland // Water. 2018. V. 10 (2). P. 195.

7. Cycoń M., Mrozik A., Piotrowska-Seget Z. Antibiotics in the soil environment degradation and their impact on microbial activity and diversity // Frontiers in microbiology. 2019. P. 10.

8. Davies J., Davies D. Origins and evolution of antibiotic resistance//Microbiology and molecular biology review. 2010. V. 74. P. 417-433.

9. Dixit R., Malaviya D., Pandiyan K., Singh U.B., Sahu A., Shukla R., Singh B.P., Rai J.P., Sharma P.K., Lade H., Paul D. Bioremediation of heavy metals from soil and aquatic environment: an overview of principles and criteria of fundamental processes // Sustainability. 2015. V. 7 (2). P. 2189-2212.

10. Gupta A., Joia J., Sood A., Sood R., Sidhu C., Kaur G. Microbes as potential tool for remediation of heavy metals: a review // Journal of microbiology, biochemistry and technology. 2016. V. 8 (4). P. 364-372.

11. Igiri B.E., Okoduwa S.I., Idoko G.O., Akabuogu E.P., Adeyi A.O., Ejiogu I.K. Toxicity and bioremediation of heavy metals contaminated ecosystem from tannery wastewater: a review // Journal of toxicology. 2018.

12. Jackson M.L. Soil Chemical Analysis. Prentice Hall of India Private Limited, New Delhi. 1973.

13. Jensen H.E., Jørgensen L.N. Use of antifungals in animals and agriculture-any impact on human infections? // Mycoses. supplementary. 2013. V. 56 (Suppl. 3). P. 32.

14. Kumar A., Kumar A., Patel H. Role of microbes in phosphorus availability and acquisition by plants // International journal of current microbiology and applied Sciences. 2018. V. 7 (5). P. 1344-1347.

15. Lubelski J., Konings W.N., Driessen A.J.M. Distribution and physiology of ABC-type transporters contributing to multidrug resistance in bacteria // Microbiology and molecular biology reviews. 2007. V. 71 (3). P. 417-433.

16. Mahidi S.S., Hassan G.I., Hussain A., Rasool F. Phosphorus availability issue-its fixation and role of phosphate solubilizing bacteria in phosphate solubilization-case study // Research journal of agriculture science. 2011. V. 2 (1). P. 174-179.

17. Rodríguez H., Fraga R. Phosphate solubilizing bacteria and their role in plant growth promotion // Biotechnology advances. 1999. V. 17 (4-5). P. 319-339.

18. Satyaprakash M., Nikitha T., Reddi E.U.B., Sadhana B., Vani S.S. A review on phosphorous and phosphate solubilising bacteria and their role in plant nutrition // International journal of current microbiology and applied sciences. 2017. V. 6 (4). P. 2133-2144.

19. Walkley A. A Critical Examination of a Rapid Method for Determining Organic Carbon in Soils: Effect of Variations in Digestion Conditions and of Inorganic Soil Constituents // Soil science. 1947. V. 63 (4). P. 251-264.

20. Walpola B.C., Yoon M. Prospectus of phosphate solubilizing microorganisms and phosphorus availability in agricultural soils: a review // African journal of microbiology research. 2012. V. 6 (37). P. 6600-6605.

21. Wright G.D. Antibiotics: A new hope//Chemistry and biology. 2012 . V. 19 (1). P. 3-10.

22. Wright G.D. Molecular mechanisms of antibiotic resistance // Chemical communications. 2011. V. 47 (14). P. 4055-4061.

23. Wright G.D., Poinar H. Antibiotic resistance is ancient: Implications for drug discovery // Trends in microbiology. 2012. V. 20 (4). P. 157-159. 